\title{
Covert Insubordination in Arus Balik Novel of Pramoedya Ananta Toer: Perspective of Social Movements
}

\author{
${ }^{1}$ Setya Yuwana Sudikan, ${ }^{1}$ Tengsoe Tjahjono \\ ${ }^{1}$ Faculty Languages and Arts, State University of Surabaya \\ setyayuwana@unesa.ac.id
}

\begin{abstract}
The aim of this study was to describe the covert insubordination in Arus balik Novel of Pramoedya Ananta Toer. The theory used is a covert insubordination theory within perspective of social movements. This theory was the rational actions of individual leaders but not in the category of rational choice theory, there are not open, take place informally, not stated, and on a small scale. This study applied a descriptive qualitative approach. Data source Arus balik Novel of Pramoedya Ananta Toer. The data of this research were word, phrase, sentence, paragraph, and discourse associated with the focus of the research.The technique of data analysis techniques was hermeneutics. Research procedures, namely: 1) heuristics, and 2) retroactive. The findings of this study suggests there are five figures shrouded in insubordination, namely: 1) covert insubordination Arya Teja Wilwatikta against Majapahit, 2) covert insubordination against Adipati Cluring Rama Arya Teja Wilwatikta, 3) betrayal of Adipati Wilwatikta against the Adipati Unus who deliberately late five days of sending the troops to attack Portuguese in Malacca Strait result in Jepara's forces easily defeated by Portuguese, 4) betrayal of Sunan Rajeg (Isaac Indrajit) against the Adipati Wilwatikta patterned economic resentment and because it removed from Office as Harbour replaced Sayid Habibullah Almasawa, 5) betrayal of Sayid Harbour Habibullah Almasawa which has a political agenda like to master and monopolize trade in Tuban port who conspired with Portuguese trading fleet in Tuban area, and 6) covert insubordination against Chief Minister Wiranggaleng Tuban and Adipati Arya Teja Wilwatikta.
\end{abstract}

Keywords: covert insubordination; rational action; economic political; moral; economic; and social movements

\section{Introduction}

The decline of power due to a coup from within, competition becomes King and Grand Vizier of Majapahit. Kings of the coast of Java, coup d ' état with the help of the Islamic Empire. The Kingdom of Islam has an interest to expand power and monopolize trade in the archipelago. Arya Cassia became the Supreme ruler since served as the Chief Minister of the Majapahit Empire (after the death of the Grand Vizier Gajah Mada), with the title of Tumenggung Wilwatikta. Arya Teja ruled the Majapahit Empire after a period of decline and collapse. He was discouraged, so focusing more on its own territory, i.e. the land of Tuban.

Pramoedya Ananta Toer in the Arus Balik novel relates contextually the occurrence of trade as well as the process of acculturation of ideology, culture, religion, and economy, in the 16th century AD. The main background is told about port town of Tuban, yet battering events are much broader, change, and shift. The area is narrated through to Jepara, Demak, Lasem, Pajajaran with city of Banten, Sunda Kelapa Harbour to Panarukan and Blambangan even to Malay peninsula by Sultanate of Malacca. The main theme is revealed in novel is fall of Majapahit and collapse into a small area, and describes the beginning of trading occurs in archipelago. Small region was governed by a Adipati who had each trading port and trade with Arab traders, merchants, and Portuguese India. The story is continued racer, Islam brought by Arab traders and India, to pervasive spread across the archipelago.

The arrival of Portuguese trading fleet as early as the fall of Malacca Sultanate until Portuguese controlled trade route. He narrates that since long ago in Malay Archipelago, there is international trade, between the coastal territory with traders from Arabia, India, 
China, and Europe. The traders are not only trade, but also carry and spread the ideology, religion, socio-cultural, economic and political, for purpose of conquer and occupying the country.

Pramoedya Ananta Toer revolves around using scientific realism. The story in novel empirical data supported Arus Balik socially has historical and logical. He described that the story as a point of Feedback began to assimilate Java with political ideology, political, religious, cultural, social, economic and taken by the respective merchants who trade in archipelago. Arab traders brought ideology and religion of Islam. Merchants from India bringing ideology and Hinduism-Buddhism. Traders from China carry ideology of Confucius. Portuguese traders brought ideology of Catholic religion. Adipati of Tuban Arya Teja (Wilwatikta) felt benefited with arrival of traders as it can make crowded airport in Tuban port. The harbor became a center of Commerce, and Tuban become international trade in archipelago. Ideological and cultural assimilation took place in Tuban community.

\section{Review of Literature}

\subsection{The Theory of Covert Insubordination within the Framework of Social Movements}

This study used the theory of covert insubordination. Theories of covert insubordination is rational action and individual characters, but not in the category rational choice theory as propounded Samuel Popkins (1979), for such insubordination is not open, in progress informally, not stated, and on a small scale. Thus the position of covert insubordination theory research is eclectic between the theory of Everyday forms of Peasant Resistance (1989), and rational choice theories (Coleman, 1994), linked by strong factors the hegemony country, either ideologically or materially (Saberi, 1996).

The history farmer's movement approach in general is based on the historiography records or historical documents, such as: Chronicle, fiber, or literary poets (Kuntowijoyo, 1993-133). This resistance movement in history of note always produces a ' Hero ' is sometimes able to be suspended or even giving the legend for people's stories are passed down to goes down to posterity. The historical approach looks at the values, norms, traditions, beliefs, and myths that have been owned and inherited in down goes to down by farmers as a crucial. In this framework, the farmers ' resistance movement is understood as a result of the occurrence of irregularities and threats to the values, norms, traditions, beliefs, and myth. With this basis, historical approach typically uses the theme of fighting ideological and social changes that threaten the sustainability of social institution.

Some of ideology that had many effects of five rural people's movement, namely: Millennial, Eschatologism, Messianism, the holy war, and Revivalism (Kartodirdjo, 1973:566). Second, the political economy approach focusing on particular individual decisions regarding that action to perform a movement of resistance is choice of most effective and efficient (rational choice) in opposition to socioeconomic changes calculation based on common sense farmers will be more detrimental than his favor. The political economy approach is based on individual decision thinking or rational choice. Third, the perspective of moral economy of Scottian spearheaded by James C. Scott $(1976,1985,1989)$ and Wolf (1969), Migdal (1974) judge of people's resistance movement as a model of resistance "Asian style," a poor people's movements are weak with the anonymous, non-formal coordination through origin is same idea, small resistance and furtive. The style of people's resistance 
movement is described through the "saga" the poor at Sedaka, Malaysia, when facing the process changes with effects of marginalization that afflict the poor.

Scott (1985) States the poor farmers threatened the well-being and social status due to penetration of capital to his village. Government policy is assessed to have been shattering the form of socio-cultural order of society so they vent their anger by doing the resistance movement toward wealthy individuals and the country. Scott (1994) reveals so many acts of violence committed people as an attempt to force the House elite do what counts people as their obligations. The people's life, marked by moral ties so as to bring forth the moral economy that favor "save yourself" and keep the line of danger. Here's what the survivors put morality made a moral approach to economics is a key factors in explaining people's resistance movement. Scott shows that the everyday forms of resistance is a form of covert resistance for the people as a reaction to everyday forms of repression conducted the landlord, as the enemy with them, stands as a globally resistance to impact of green revolution that is perceived to threaten his survival. The principle of giving priority to survive is a source of moral strength which enables poor farmers reject the changes and is ready to do resistance when they are faced with a reality that does not provide other options.

\section{Methodology}

This study used a descriptive qualitative approach. Literary texts are seen as a source of research study history of covert insubordination in perspective of social movements. Data source Arus Balik Novel of Pramoedya Ananta Toer. The data of this research were Word, phrase, sentence, paragraph, and discourse associated with focus of the research. Data analysis techniques of hermeneutics. Research procedures, namely: 1) heuristics, and 2) retroactive.

\section{Discussion}

\subsection{Insubordination of Adipati Wilwatikta Tumenggung to Majapahit}

In arus balik novel told Arya Cassia form an alliance with Governors of coastal area. Governors of this erstwhile unified during the golden age. Further, Arya Teja strengthen relationships with merchants. It eventually weakened the strength and tear down. Adipati of Tuban, Arya Teja legitimized by lifting his cousin as Patih Tuban to secure its position. Patih Tuban serves as entire leader policy adviser and head of troops of Adipati of Tuban. In addition, Isaac Idrajit legitimized Adipati of Tuban as Harbour. The naming of Isaac Idrajit as Harbour because Muslim, mastering the language and Arabic script.

Arya Teja received the heritage of naval forces, which used to be a sea power of Majapahit. Arya Teja with his powers, not expanding territory, thus not being the center of Tuban civilizations, because it is satisfied with peace and security of Tuban region. Arya Teja doesn't have goals to rebuild the golden of Majapahit, but even

doing attenuation on remnants of Majapahit power through a coup d ' état. It is done by consolidating internal form an Alliance together governors of Majapahit power amplifier, and strengthen trade links with Islamic traders, thus weakening the power of Majapahit. The Majapahit Empire crumbled only into a small area, led the former Governors of Majapahit into power, and then turned into rulers in their respective territories. Consider the following data. 
"Dulu waktu Sang Adipati masih muda, jadi pembesar berkuasa di Wilwatikta, tak ada sesuatu yang berharga telah dipersembahkannya pada Majapahit. Di tangannya juga Majapahit padam sinarnya. Sekarang dalam usia tuanya, apakah yang bisa diperbuatnya? Untuk desa pinggiran ini pun tidak sesuatu. Kalian ini kawula Sang Adipati ataukah budaknya yang ditangkap di medan perang?"

"Kawula!" seseorang memberikan jawaban.

"Mengapa raja kalian tak berbuat sesuatu untuk kalian?"

"Rama!" tegur kepala desa di belakangnya. Matanya berbeliak menyemburkan api kemarahan. "Itu pemberontakan!" ia menuduh. "Paling tidak menghasut pembangkangan. Tidak lain dari Rama sendiri yang lebih mengerti aturan darmaraja."

Orang tua itu menoleh ke belakang dan tertawa.

"Benar, pemberontakan, hasutan," dua-tiga orang mulai berseru-seru (Toer, 2002:6).

"The First time Adipati is still young, so the magnifying power in Wilwatikta, there is no something valuable has been waved on. In his hands the Majapahit also turns off light. Now in his old age, what can do? For this suburban village not something. You guys is where the Adipati or his slaves that were captured on the battlefield? "

"Assistant!" someone gave an answer.

"Why king is not doing something for you guys?"

"Rama!" admonished the village head in tow. His glaring eyes breathing flames rage.

"It's an uprising!" he accused. "At the very least inciting mutiny. None other than Lord Rama himself who better understand the rules of darmaraja. "

The old man looked back and laughed.

"Right, rebellion, incitement," twenty-three people start shouting (Toer, 2002:6).

Dialogue between Rama Cluring with Awis Krambil village chief could be meant as an expression of dislike towards the leadership of the Aryan Teja in Kadipaten of Tuban. Told of the time still young Arya Teja serving as Chief Minister after the Grand Vizier Gajah Mada, Majapahit. Near the beginning of Majapahit Kingdom collapse, Arya Teja affects the coastal Governors to commit mutiny against Majapahit. Small kingdoms ever grow in coastal support adherents of Islam. Arya Teja felt he did not need to be the King of Majapahit, too broad. He felt quite small as King Wilwatikta (Tuban), who always get the tribute to the village and harbour port in his region.

Insubordination of Arya Teja against to Majapahit era, can be understood as a rational choice based on moral economy. As ruler of old, was no longer necessary to develop his power as in era of Hayam Wuruk. for hegemony people, Arya Teja raised his cousin as Vizier in Tuban. Arya Teja savor his consort countless. The son of consort was appointed as the head of village and soldier in Tuban to perpetuate power.

Rama Cluring anger peaked when the village head explained that tributes deposited to King as a form of darmaraja. The King's position was no longer as protectors of people, but as an extortionist. The people was being blackmail to perpetuate power. Consider the following data.

Ia menoleh kepada kepala desa. Bertanya: "Darmaraja? Pengayoman? Apakah yang sudah diperbuat oleh Sang Adipati Tuban Tumenggung Wilwatikta waktu para bupati pesisir mulai membangkang mempersembahkan upeti? Bukankah Sang Adipati itu rajamu sekarang? Bukankah sebagai Tumenggung Wilwatikta, penguasa tertinggi atas keamanan dan kesejahteraan ibukota Majapahit, Wilwatikta, justru ia bergabung dengan 
yang lain-lain, membangkang mempersembahkan upeti, malah tetap mengukuhi wilayah kekuasaan yang didapatnya dari darmaraja, membentang dari Tuban sampai Jepara sebuah kadipaten dengan tidak kurang dari lima buah bandar?" (Toer, 2002:12).

She turned to the head of the village. Said: Darmaraja? Protection? What is already done by Adipati of Tuban Tumenggung Wilwatikta the coastal Governors began to disobey offer tributes? Isn't that Adipati of your King now? Wasn't as Tumenggung Wilwatikta, Supreme ruler over the security and well-being of Majapahit capital, Wilwatikta, thus he joined the others, disobey offer tribute, and keep strength of territory decision of darmaraja, extending from Tuban to Jepara-a Kadipaten with no less than five harbors? " (Toer, 2002:12).

This data described the anger of Rama Cluring against Adipati of Wilwatikta. It can be meant as a form of insubordination against to Adipati of Wilwatikta. First Arya Teja served as general of Majapahit Empire, now defected to build his own empire in Tuban with support from the coastal Regent who embraced Islam. His reign of Gresik to Jepara. Adipati Wilwatikta master the five harbors.

In other parts there is a insubordination against Adipati Arya Teja Wilwatikta of Majapahit at the end of his downfall. Adipati of Tuban led the conspiracy with Regent of North coast of Java is not loyal to the Government. At the time Adipati of Tuban serving as a warlord of Majapahit. By getting support of Islam religions, Adipati of Tuban building strength in his own kadipaten in Tuban. It acts as a small King who ruled in East coast of Java that has some commercial port and harbor for trade and agricultural land. Tribute from the heads of the village in Kadipaten of Tuban which must be deposited to Majapahit was transferred to Adipati of Tuban. Consider the following data.

Dengan hati prihatin ia melihat, bahwa bekas punggawa itu mengibarkan panji-panji Islam untuk memusuhinya. Ia tidak bisa menerima ini. Ialah yang membenarkan orang-orang Islam itu mendapat perlindungan dari Sri Baginda Bhre Wijaya Purwawisesa. Ialah pula yang mempelopori persekutuan kerjasama dengan pedagang-pedagang Islam dari Atas Angin, mengakibatkan pembangkangan bupati-bupati pesisir terhadap Majapahit dan mengakibat kan keruntuhan kerajaan Buddha Tantrayana itu. Ialah pula yang membenarkan putraputranya masuk Islam dan berpihak pada Islam. Sekarang dengan panji-panji Islam pula, seorang bekas punggawa, bekas Syahbandarnya telah mengambil sikap memusuhinya (Toer, 2002:216).

With hearts are concerned, he saw that the former retainer that hoist the banner of Islam to against him. He could not accept this. Former retainer justifies the Muslims it gets protection from the Sri Wijaya Bhre King Purwawisesa. Former retainer also initiating an Alliance partnership with Muslim traders from the top of the wind, resulting in coastal Governors of insubordination against Majapahit and led to the collapse Buddhist Empires. Former retainer also allowed his sons to Islam and in favour of Islam. Now with banner of Islam, a former retainer, the former harbor has taken attitude to against him (Toer, 2002:216).

The data show concerns Rama Cluring against Adipati Arya Teja Wilwatikta, who pioneered the alliance cooperation with Islamic traders which resulted in coastal Governors of disobedience against Majapahit. Adipati Arya Teja isn't loyal, and not loyal to the values, traditions, and customs of tantrayana Buddhism move converted to Islam. Disobedience was meant as hostility against Majapahit, whereas Arya Teja Wilwatikta previously served as harbour Tuban. 


\subsection{Insubordination of Rama Cluring}

Ideological battles fought between maintaining religious traditions of Majapahit, Buddha, Vishnu, Shiva, and his acceptance of Islam in the land of Tuban. Most old people still want to defend Buddhism, but the Adipati of Tuban opening up to the entry of the religion of Islam. The second son of the Adipati of Sayid, Raden (Sunan Kalijaga) and Raden Daniel thus deepened the Islamic religion in the Kingdom of Demak. A Buddhist teacher compares golden leadership of the Adipati Wilwatikta in Tuban. Consider the extract data in the following.

"Berbahagialah kau yang bisa bersakit hati, pertanda masih ada hati, dan ada cinta di dalamnya. Tapi macam cinta apa kau kandung dalam hatimu? Cinta pada kekebalan adalah juga kekebalan. Nah, sekarang coba ikuti kata-kataku: telah kalian ubah nama ini dari Sumber Raja jadi Awis Krambil, hanya karena desa ini tak mampu membayar upeti kelapa kepada pasukan gajah Tuban. Upeti demi upeti. Apa sudah kalian terima dari Sang Adipati? Siapa di antara anak-anak desa ini mendapatkan kesempatan merajai lautan seperti di jaman Majapahit dulu? Menyaksikan dunia besar? Dihormati dan disegani di mana-mana? Di Tumasik, di Benggal, Ngabesi, Malagasi, sampai Tanjung Selatan Wulungga sana? Tak pernbahkah orang tua kalian bercerita semacam itu maka hatimu jadi sakit karena kekebalan sendiri?"

Tak ada seorang pun di antara pemuda desa ini pernah menginjakkan kaki di bumi Atas Angin. Di sana pun dahulu kalian akan dengar gamelan kalian sendiri. Orang sana juga menggemari cerita-cerita Panji dari Jenggala seperti kalian. Mereka juga mencintai Panji Semirang, juga seperti kalian di desa ini. Sang Adipati tidak memberikan kesempatan pada kalian. Tapi kalian terus juga membayar upeti, barang jadi dan barang gubal. Tak seorang di antara kalian menyaksikan jauh-jauh di seberang sana bagaimana Dewa Ruci dan Arjuna Wiwaha didengarkan orang." (Toer, 2002:5).

"Blessed are you who can brokenhearted, sign is still there, and there is love in it. But the kinds of love what you had in your heart? Love on immune is also immune. Well, now try to follow my words: have you changed the name from a King to Krambil Awis, just because the village cannot afford to pay coconut kelapa to elephant army Tuban. Tribute for the sake of tribute. What you have already received from Adipati? Who among the sons of village get a chance majority of oceans as Majapahit era in first? Witness the big world? Honored and respected everywhere? In Tumasik, in Benggal, Ngabesi, Malagasy, South of Cape Wulungga until there? Never parents telling you sort it then your heart so pain because their own amnesty? "

No one among the youth of village, never set foot on Earth. Are there any first you will hear your own gamelan. People there are also fond of stories of Jenggala Banners as you. They also love the Banner Semirang, as like you in the village. The Adipati doesn't give a chance at you. But you continue to also pay tribute, finished commodity and gubal commodity. No one among you watched all the way across from there how Gods Ruci and Arjuna Wiwaha text, listening to people. " (Toer, 2002:5).

The data shows the turmoil figure Rama Cluring to changes which occurred in Tuban. First, because the majority of respected Majapahit. Life assurance society used to get protection from the King of Majapahit. The sailors can sail the seas of Tuban to Tumasik, in 
Benggal, Ngabesi, Malagasy, until South of Cape Wulungga. It to show braveness the Tuban sailors. Rama Cluring looked past as the greatness that should be repeated in present and future. Such data can be approached through a historical approach that looks at the values, norms, traditions, beliefs, and myths that have been owned and inherited in down goes to down by the community can be used as a handle for life on present and the future, by rejecting the presence of new ideology from outside. It is reinforced by the following data.

"Dewa Batara!" sebutnya keras, berpaling cepat pada kepala desa. Kemudian menudingnya: "Lihatlah ini tampang kepala desamu, takut pada kebenaran, pada keadilan, agar dia tetap jadi kepala desa, dia telah racun aku! Dan kalian kenal siapa aku, hanya seorang pembicara yang menggaungkan kebenaran milik Maha Dewa." (Toer, 2002:15).

"The God Batara!"said in hard, turned quickly on the village chief. Then accused him: "look at this look head of village, afraid of the truth, to justice, so that he remains so the village chief, he has poison me! And you know who I am, just a speaker that vocalize the truth belongs to the God Almighty. " (Toer, 2002:15).

Anger peaked when Cluring Rama poisoned by Awis village chief Krambil, and Rama Cluring just a teacher streams of Hindu-Buddhist beliefs in a village far from power. Rama Cluring wanted to alert back to golden of Majapahit. It can be meant as the people's disobedience against the Adipati of Wilwatikta in Tuban.

\subsection{Insubordination of Harbour Sayid Mahmud Al-Badawi against Sultan Mahmud shah}

On the other part, was introduced to readers of treason which continued into disobedience committed by Sayid Mahmud Al-Badawi, a harbour of Malacca Arab nationals during the reign of Sultan Mahmud Shah. Malacca fell to Portuguese because of their plotting between Sayid Mahmud Al-Badawi with a Portuguese trading fleet. Consider the following data.

Tidak lebih dari lima hari kemudian, di taman ditentang kandang gajah ini juga datang menghadap seorang utusan rahasia dari Sultan Mahmud Syah yang sedang menyingkir ke pembuangan. Ia mempersembahkan sepucuk berbahasa dan bertulisan Jawa.

Sultan mengabarkan, Malaka telah jatuh ke tangan Peranggi sebagai akibat pengkhianatan Syahbandar Malaka berkebangsaan Arab bernama Sayid Mahmud AlBadawi. Diterangkan orang itu berbadan kurus tinggi, agak bongkok, setengah umur, berkumis, berjenggot, dan bercabang-bauk yang telah bersulam uban dan berhidung bengkok rajawali.

Sultan Malaka mengakui, ia telah keliru mengangkat orang tersebut, hanya karena terbujuk oleh kefasihan tersebut dan kepandaiannya mengambil hati orang. Menjelang jatuhnya Malaka ia malah mendapat kepercayaan keluar-masuk istana, dan hampirhampir diangkat menjadi wazir.

Sultan berseru pada Sang adipati sebagai sedarah-sedaging, seasal-seketurunan Majapahit, supaya berhati-hati terhadap orang tersebut sekiranya ia berada di Tuban, karena orang itu telah meninggalkan Malaka di bawah perlindungan Peranggi.

Sang Adipati mengerti maksud surat itu. Orang yang dimaksudkan tidak lain dari Sayid Habibullah Almasawa. Ia tak terkejut. Berubah pun airmukanya tidak (Toer, 2002:105-106). 
No more than five days later, the Park was opposed this elephant enclosure also came before a secret Envoy of Sultan Mahmud Shah was being forced into exile. He offered a speak and read Java.

Sultan preaches, Melaka had fallen into the hands of Peranggi as a result of the treason of the Harbour of Malacca-born Arab named Sayid Mahmud Al-Badawi. Explained the man travelling on a skinny tall hunchback, rather, half his age, mustachioed, bearded, and branched badly who has gray hair and crooked-nosed embroidered Eagle.

The Sultan of Malacca, admitted he had falsely raised, simply because that person is enticed into such extraordinary intellect and eloquence by taking people's hearts. Leading up to the fall of Malacca he won the trust of transitions at Court, and almost was appointed Vizier.

The Sultan cried on Adipati of as relation blood, cognate of Majapahit, so be wary of that person if it is located in Tuban, because that person has left the Malacca under the protection of Peranggi.

The Adipati understand the intent of the letter. The person who meant nothing other than Sayid Habibullah Almasawa. He was not surprised. Change any face expression is not all. (Toer, 2002:105-106).

The data of the text of a letter sent by Sultan Mahmud Syah to Arya Adipati Wilwatikta Teja in Tuban, brought a courier fugitive soldiers from Sultanate of Malacca. The content of letter was preaching so that Adipati Arya Teja carefully on a man named Sayid Mahmud Al-Badawi because the traitor Sultanate of Malacca. Physical traits of character Sayid Mahmud Al-Badawi ever narrated in details. Sultan Sultan Mahmud Shah felt wrongly choose Sayid Mahmud Al-Badawi as the harbour of Malacca.

Arya adipati Teja Wilwatikta unstoppable against the contents of letters sent, Sultan Mahmud Shah. He understands that what is meant by the name Sayid Mahmud Al-Badawi is Sayid Habibullah Almasawa. This figure was appointed by Adipati Arya Wilwatikta as Teja Harbour in Tuban port.

After serving as a harbour port of Tuban, for many years, Sayid Habibullah Almasawa making his way i.e. in cooperation with Portuguese naval fleet to drop authority and the Government of Adipati Arya Wilwatikta Teja in Tuban.

\subsection{Insubordination Rangga Iskak to Adipati Teja in Tuban}

The replacement Harbor office in Tuban from Rangga Iskak to Sayid Habibullah Almasawa, carrying the logical consequence of discontent Rangga Iskak to Arya Adipati Teja. Compensation is awarded the Adipati Arya Teja Wilwatikta is five villages in the region in order to be managed by Rangga Rajeg Iskak is seen still far from expectations. In the village of Rajek, Rangga Iskak build strength along the fugitive warrior from Melaka to conduct insubordination to Adipati Arya Teja Wilwatikta. Rangga Iskak changed its name to Sunan Rajeg. Consider the following data:

Persembahan terakhir membenarkan dugaannya prajurit pelarian Malaka itu menggabung kan diri dengan Rangga Iskak di desa Rajeg.

Sudah berkali-kali ia memanggil putra-putranya di Demak untuk dimintainya nasihat, dan untuk menjadi juru pendamai terhadap pembangkangan baru ini. Tak seorang pun di antara mereka datang menghadap. Pembangkang Islam hanya bisa diredakan orang Islam 
pula, pikirnya. Dan sekarang ia menghadapi pembangkangan dari putra-putranya sendiri. Menjawab pun mereka tidak. Ia sudah sediakan alasan secukupnya, mengapa gugusan Tuban terlambat datang. Dan mereka tetap tidak muncul (Toer, 2002:217).

\section{data lain:}

"Tetapi keadaan sudah berubah," Sang Patih meneruskan. "Jabatannya sebagai Syahbandar tak dapat dipertahankan. Ia harus diganti. Tetapi ia tidak rela diganti, ia merasa bandar Tuban adalah miliknya pribadi. Segala apa pun yang dikaruniakan Gusti Adipati, dianggapnya kurang dan makin kurang. Memang dasar raksasa bergigi taring. Karunia lima buah desa sudah selayaknya ia merasa jadi seorang bupati. Tetapi tidak, dengan desa itu ia semakin bertingkah. Ia anggap desa-desa itu didapatnya dari berperang, dan sekarang dipergunakannya jadi modal untuk melawan ...(Toer, 2002:241).

The last offerings justify the conjecture that Malacca fugitive soldier merging right themselves by Rangga Iskak Rajeg village.

Already many times he summoned his sons in Demak was asked for advice, and to be a reconciler spokesman against the mutiny. None of them came. Dissident of Islam could only be assuaged Muslims anyway, he thought. And now he is facing dissent from his own. They answered no. He had already prepared an excuse to taste, why clusters of Tuban late coming. And they still don't show up (Toer, 2002:217).

\section{other data:}

"But circumstances have changed," The Minister continued. "As the Harbour cannot be sustained. He should be replaced. But he is not willing to be replaced, he feels are his private airport in Tuban. All whatever given Gusti Adipati, deems it less and less the more. Basic canine toothed Giants indeed. The gift of five villages already should he feel so a Regent. But no, with the village he is increasingly acting up. He considered the villages it gets from fighting, and are now used so capital to fight ... (Toer, 2002:241).

The data showed insubordination Rangga Iskak (Sunan Rajeg) against the Adipati Arya Teja Wilwatikta in Tuban. The character feel aggrieved because it removed from Office as harbour Tuban was replaced by Sayid Habibullah Almasawa or Sayid Mahmud Al-Badawi Al-Tholib aka Sungkar Zubaid. Insubordination can be viewed as a rational course of action because the Insects lose production source Iskak which consists of money Customs ship, recliner, and others. This defiance was crushed by Wiranggaleng before becoming an open rebellion.

\subsection{Duke Wilwatikta Tumenggung Disobedience to Demak}

Secretly Arya Adipati Teja Wilwatikta do dissent against Adipati Unus in Jepara. The form insubordination is shipping soldiers to battle five days late to Malacca. Delivery delays this weakens the power of warrior war Adipati to beat Portuguese in Malacca. Consider the following data:

Dengan diantarkan oleh pembantu-utamanya Raden Kusnan mendarat dan berjalan tergesa-gesa di kadipaten Jepara. Di sana tak ada mereka jumpai Adipati Unus Jepara. Yang ada justru abang Raden Kusnan sendiri Ki Aji Kalijaga.

Wiranggaleng melihat bagaimana Ki Aji mengeluarkan tangan kanan dari balik kain batik penutup dada. Dan terdengar suaranya, tenang, terang, kata demi kata: "Buyung! Mengapa Tuban lima hari terlambat datang?" 
Dalam simpuhnya Raden Kusnan menjawab: "Ampun, Kakanda Aji, ada pun yang menentukan keberangkatan bukanlah patik. Tidak lain dari ayahanda sendiri Gusti Adipati Tuban."

Ki Aji memasukkan kembali tangannya ke balik kainnya.

"Itu tidak patut," katanya pelahan. "Biarpun seorang ayah, seorang adipati, orang tak patut membikin malu anaknya." (Toer, 2002:191).

\section{data lain:}

Dalam kamarnya yang sempit juara gulat itu melihat wajah Raden Kusnan telah kehilangan kepucatannya, kini merah-hitam dibakar oleh kemarahan.

"Aku percayakan padamu, tak boleh ada orang tahu tentang keterlambatan

Tuban yang disengaja ini. Lima hari! Terlambat lima hari!"

"Mereka semua sudah tahu Gusti."

"Bedebah! Bagaimana mereka bisa tahu?"

"Mereka tak melihat armada Jepara."

"Mereka harus percaya, armada Jepara ada dekat di depan kita. Mengerti?

"Mereka pelaut-pelaut yang mengerti tentang laut dan kapal, Gusti!"

"Aku tak percaya mereka tahu."

"Ya, Gusti, mengapa Gusti berkata demikian? Bukankah semua mereka kawula Gusti sendiri? Bukankah mereka bukanlah gerombolan kambing bodoh yang tidak tahu apa-apa, Gusti, tapi kawula Gusti sendiri." (Toer, 2002:193).

With delivered by maid-whose main Raden Daniel landed and walked hastily in Kadipaten of Jepara. There's nothing they meet Adipati Unus Jepara. There is thus a brother Raden Daniel own Ki Aji Kalijaga.

Wiranggaleng see how Ki Aji issued a right hand from behind the batik cloth cover the chest. And her voice sounds, quiet, light, Word for Word: "Pitcher! Why is Tuban five days coming late?"

In his bend Raden Kusnan replied: "Pardon, me, Kakanda Aji, specify the departure is not patik. None other than his own Gusti Adipati Tuban. "

Ki Aji re-enter his hand behind his mantle.

"It's inappropriate," he said slowly. "Even a father, an Adipati, not people ought to be ashamed of his son raise." (Toer, 2002:191).

\section{other data:}

In his cramped wrestling champion was seeing the faces of Raden Kusnan has lost pale, now black burned by anger.

"I trust you, no people know about the deliberate delay in Tuban. Five days! Five days late! "

"They all already know later on."

"Shithead! How could they know? "

"They don't see a fleet of Jepara."

"They must believe, the fleet there is near Jepara in front of us. Understand?

"Those sailors who understand about the sea and ships, Gusti!"

"I can't believe they know."

"Yes, Gusti, why Gusti said so? Not all their subjects themselves? Gusti Aren't they stupid goat Horde is not who does not know anything, Gusti, kawula Gusti but himself.

" (Toer, 2002:193). 
The dialogue on the data shows the deliberate action of the Adipati of Tuban late five days in sending soldiers towards the ground and Malacca. The delay meant as rational action, that Tuban is not willing to help with a vengeance to Adipati Yunus. In addition, the inexperienced Raden Kusnan in the war at sea or on land designated as a warlord leading the soldiers heading to Malacca. It as a form of humiliation. On the way, informed by leadership was taken over by Wiranggaleng. Wiranggaleng as warlord tuban at sea or on land.

In the war against Portuguese in Malacca, Jepara, Demak, Tuban and easily defeated by the Portuguese. The Mission disobedience of Adipati Arya Teja Wilwatikta, uncontested. The small Kingdom of Tuban in East Java's North Coast do not want under Muslim rule in Demak and Jepara. The Kingdom has repeatedly attacked by Warriors of Demak Tuban by road.

\subsection{Insubordination Wiranggaleng to Patih Tuban}

Wiranggaleng requires an assertive leader, wise, and sided with the State. He has long been waiting for certainty what to do by Senapati war faced a revolt from the village of Rangga Iskak Rajeg, don't let it drag on. Patih Tuban did not immediately decide the rebellion. Likewise Adipati Arya Teja Wilwatikta indecisive faced Rangga Iskak. To face it, the Wiranggaleng chose to kill Patih Tuban with his creese in the presence of soldiers and Tuban people.

Melihat Sang Patih mulai bermain teka-teki tidak menentu dan perintah tidak juga dijatuhkan, tahulah Wiranggaleng, Senapati Tuban memang tidak mempunyai niat untuk bertindak. Di samping Peranggi dan Sunan Rajeg, Senapati Tuban sendiri kini berdiri di hadapnya sebagai musuh Tuban. Ia kebaskan apitan, melompat menerjang lingkaran, mencabut keris dan menikam Sang Patih pada pinggangnya.

Orang-orang itu terpekik.

Sang Patih terhuyung ke depan dan tertahan oleh keris dengan seluruh mata masuk ke dalam tubuhnya. Dan hulu keris itu masih tetap dipegangi oleh kepa pasukan laut Wiranggaleng.

"Ampuni patik, Gusti Patih Senapati Tuban!" pekik juara gulat itu dengan suara lantang.

"Baik. Aku ampuni kau, Galeng. Barangkali ke medan perang. Kau Gajah Mada baru. Hanya kau dapat kerahkan seluruh balattentara. Aku ampuni kau! Tapi semua akan percuma selama raja-raja adalah seperti Gusti Adipati, gustiku."

Ia tak mengedipkan mata pada orang yang menikamnya. Tubuhnya mulai meliuk, jatuh ke tanah (Toer, 2002:341).

Seeing the Patih start play puzzles and erratic command does not also dropped, knew Wiranggaleng, Senapati Tuban indeed does not have intention to act. In addition to Peranggi and Sunan Rajeg, Senapati Tuban alone now stands in front as enemies of Tuban. He shake it of clamp, jump lunge circle, and revoke creese and stabbing Sang Patih at his waist.

People were let out a scream.

Sang Patih staggered forward and held up by creese with all eyes went into his body. Creese handle is still holded by kepa ,Wiranggaleng naval forces.

"Please forgive patik, Gusti Patih Senapati Tuban!" alarm that wrestling champion with a loud voice.

"Either. I forgive you, Galeng. Perhaps to the battlefield. You're new Gajah Mada. 
Just you can muster a whole army. I forgive you! But all will be useless during the Kings are like Gusti Adipati is my Gusti. "

He can't wink at the person who stabbed him. His body began to bend, fall to the ground (Toer, 2002:341).

These data demonstrate the courage of Wiranggaleng is being to save the integrity of nation and the State. Rational action taken Wiranggaleng by killing his superior Sang Patih Tuban. It can be seen as insubordination, although Wiranggaleng does not want the post of Grand Patih as Adipati in Tuban. After committing murder, Wiranggaleng apologises to Sang Patih Tuban. The penalty given by Adipati Tuban accepted gracefully. He chose to return home in the village of Awis Krambil for farming with his wife (Idayu) and his son's title.

\section{Conclusion}

In Arus balik novel by Pramoedya Anantta Toer, there are 6 (six) covert insubordination First, the treason continued disobedience committed by Arya Teja termed Adipati Wilwatikta against power by doing a collaboration with Governors of coastal Majapahit Empire that made collapse. Second, the mutiny Rama Cluring against Adipati Arya Teja Wilwatikta in Tuban through speech in front of the Awis Krambil community. Third, the treason and mutiny of Adipati Wilwatikta against Adipati Unus who deliberately late five days of sending the troops to attack Portuguese in Malacca Strait result in Jepara's forces easily defeated by Portuguese.

The four the betrayal of Sunan Rajeg (Isaac Indrajit) against Adipati Wilwatikta patterned resentment and economic because it removed from Office as Harbour replaced Sayid Habibullah Almasawa. In disobedience and rebellion against the Adipati wilwitikta of Tuban, Sunan Rajeg assisted two Portuguese Esteban and Rodriquez. Fifth, the betrayal of Harbour Almasawa Habibullah Sayid has a political agenda want to master and monopolize trade the port of Tuban which conspired with Portuguese trading fleet in the area of Tuban. Sixth, a covert disobedience Wiranggaleng against Patih Tuban and Adipati Arya Teja Wilwatikta.

\section{References}

Adas, Michael. 1979. Ratu Adil: Tokoh dan Gerakan Milenarian Menentang Kolonialisme Eropa. (Penerjemah M. Tohir Effendi). Jakarta: Rajawali.

Ashar, Ipong. 1999. Radikalisme Petani pada Masa Orde Baru: Kasus Sengketa Tanah Jenggawah. Yogyakarta: Yayasan Untuk Indonesia.

Bangsawan, Anandito Reza. 2017. Pramoedya Ananta Toer, Politik, \& Sastra. Yogyakarta: Media Pressindo.

Bates, R. H. 1981. Markets and States in Tropical Africa: The Political Basis. Berkeley: University of Agricultural Politics.

Coleman, James C. 1994. "A Rational Choice Perspective on Economic Sociology," in The Handbook of Economic Sociology, Smelser, Neil J and Richard Swedberg (ed) 1994. New York: Princeton University Press, Pinceton and Russel Sage Foundation.

Kartodirdjo, Sartono. 1973. Protest Movement in Rural Java: A Study of Agrarian Unrest in the Nineteenth and Early Twentieth Centures. Singapore: Oxford University Press.

Kuntowijoyo. 1993. Radikalime Petani. Yogyakarta: Bentang Intervisi Utama. 
Migdal, Joel S. 1974. Peasant, Politics and Revolution: Pressures toward Political and Social Change in Third World. Princeton: Princeton University Press.

Moore, Barrington. 1966. Social Origin of Dictatorship and Democracy. Boston: Beacon Press.

Popkin, Samuel L. 1979. The Rational Peasant The Political Economy of Rural Society in Vietnam. Berkeley: University of California Press.

Scott, James C. 1976. The Moral Economy of Peasant. New Haven: Yale University.

Scott, James C. 1985. Weapons of the Weak: Evereday Form of Resistance. New Haven: Yale University.

Scott, James C. 1989. Evereday Form of Resistance, Peasant Resistance. New York: Rmunck Me Sharpe.

Scott, James. 1994. Moral Ekonomi Rakyat: Pergolakan dan Subsistensi di Asia Tenggara.

Siahaan, Hotman M. 1996. "Pembangkangan Terselubung Rakyat dalam Program Tebu Rakyat Intensifikasi Sebagai Upaya Mempertahankan Subsistensill," Surabaya: Pascasarjana Universitas Airlangga (Disertasi, tidak diterbitkan)

Toer, Pramoedya Ananta. 2002. Arus Balik: Sebuah Epos Pascakejayaan Nusantara di Awal Abad 16. Jakarta: Hasta Mitra

Wolf, E.J. 1969. Peasant Wars of Twentieth Centure. New York: Harper \& Rowy. 